\title{
Social worker registration: A decade of development, debate and delivery
}

Barbara Gilray

Barbara Gilray, Social Work Advisor, Social Workers Registration Board.

\section{Introduction}

The Social Workers Registration Act was enacted into Aotearoa New Zealand law in April 2003 and provides the framework for the registration of social workers. In general the Act prescribes entitlement to and criteria for registration; competence and fitness to practise social work; and discipline and complaints procedures.

The Act was preceded by wide consultation and debate about the possible impact registration would have on those who practise social work and the profession in general. A number of concerns were raised, including;

- professional accountability,

- best practice principles,

- public protection,

- disciplinary processes,

- resourcing,

- authority,

- the perceived development of a hierarchical system of social work education delivery.

Particular concern was raised about the potential impact of academic requirements on social workers who were seen to be competent practitioners, but lacked formal qualifications. The concern was that such workers could become marginalised by the process.

At the inauguration of the Act in November 2003, Imelda Dodds, the then President of the International Federation of Social Workers, said:

I have been a campaigner for the registration for social workers for a very long time. My reasons are plain and simple. Our work typically brings us into contact with some of the most disadvantaged, marginalised and vulnerable people in our community. Therefore we must be ready, willing and able to demonstrate that our skills, knowledge and competence to practise are of the highest order and we must be accountable as a profession for any failure on our part to deliver that service (Dodds 2004: 2).

A decade later, this discussion will explore the current situation and future challenges facing social worker registration in Aotearoa New Zealand.

\section{Current situation}

The Social Workers Registration Act 2003 brings Aotearoa New Zealand into line with countries such as Canada, England, France, Northern Ireland, Scotland, South Africa, the 
United States, Hong Kong, Romania and others which have moved to professionalise and regulate social work. The main aim internationally is to protect the public and to ensure minimum standards of social work practice.

The number of social workers becoming registered in Aotearoa New Zealand is increasing each year, and over the last four years the Board has calculated that the average percentage increase in applications for registration per year has been $38 \%$.

It is heartening that in a non-regulatory environment, to date over 4,000 social work practitioners have opted to meet the professional standards required for social worker registration.

Overall an increasing number of younger social workers are applying to become registered, with approximately $4.6 \%$ being 30 years of age or under at the time of application. As in decades prior and for a host of reasons which have been well canvassed, the profession of social work continues to be a female-dominated one. To date however, $17 \%$ of those who have met the requirements to be registered social workers are men.

Since 1 July 2012:

- 3,321 Annual Practising Certificates have been issued,

- 465 additional social workers have been registered,

- 453 new applications for registration have been received,

- 271 full competence assessments have been undertaken,

- 115 competence assessments recertifications have been undertaken.

As at 31 March 2013 a total of 3,923 social workers were registered, with the majority $(2,401)$ working in the district health board (DHB) and Child, Youth and Family sectors. See Table one.

Table one. Number and percentage of 3923 registered social workers by employer.

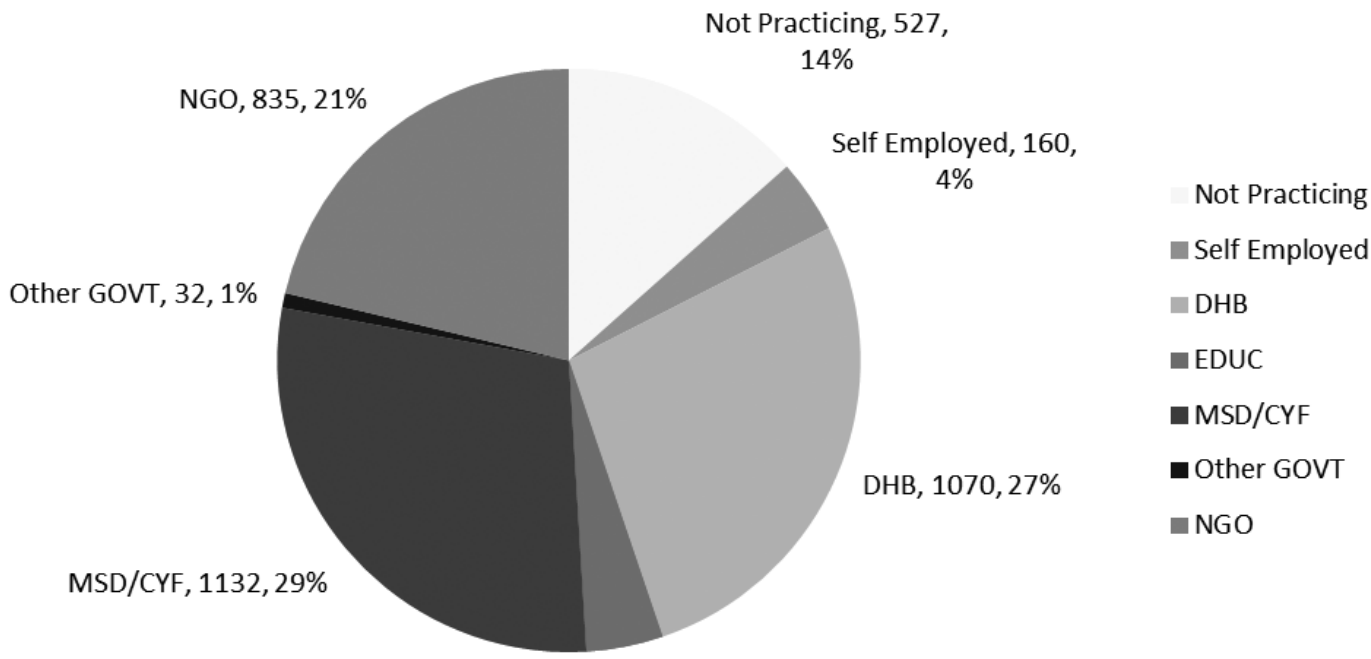

EDUC, 167, $4 \%$ 
It is not surprising that DHBs feature highly in these statistics, as health boards in general are well used to their professional workforce being registered. Most therefore view the registration of social workers as a necessity. The majority of DHBs have social worker registration policies in place, and failure to register within a defined timeframe can constitute a breach of internal codes of conduct.

It was widely anticipated by the non-governmental organisation (NGO) and government social service sectors that the 2012 White Paper for Vulnerable Children (Ministry of Social Development 2012a) would recommend the mandatory registration of social workers. In anticipation of this, initial planning had been undertaken by many employers, including Child, Youth and Family. Although it signalled that, 'The most commonly suggested ideas about competencies and skills were that the workforce should have formal qualifications ...', mandatory registration did not form part of the White Paper's outcomes. The Children's Workforce Action Plan, developed as part of the Government's White Paper for Vulnerable Children, will however contain actions to promote and support registration for social workers, for example through funding contracts.

The White Paper noted that increasing social worker registration on its own would not enhance social work competence, but that the Children's Workforce Action Plan would also set out actions relating to the monitoring of on-going social work practice, the supervision and administrative support needed, and the role of tertiary institutions, the Social Workers Registration Board and employers in developing quality education programmes.

As a result of recognising the need to promote and support social worker registration, many NGOs and those in government continue to support and encourage their front-line social workers to become registered. One notable example of this is that the new strategic plan for Child, Youth and Family, 'Mā mātou, mā tātou changing young lives', sets out the goal and expectation that Child, Youth and Family's entire professional workforce will be registered by 2015.

The Board of the Social Workers Registration Board (SWRB) is committed to ensuring that the aims and aspirations of Māori in the registration process remains a priority. It has stated that in moving to mandatory registration the Board will work with Māori social service providers to ensure a bi-cultural approach and to better provide for a culturally inclusive registration process. $19 \%$ of social workers who are registered have self-identified as being of Māori descent. See Table two.

One of the main requirements of competency and subsequent registration involves the demonstration of specific competencies to work with Māori and other cultural and ethnic groups.

Demonstration of these competencies is generally easier for locally trained social workers, as Aotearoa New Zealand training institutions have programmes of study which, '... focus on learning how to practise social work with those of Māori descent and other cross-cultural groups specific to the country...' (Bartley et al. 2011: 24).

It is the SWRB's experience that while many overseas applicants, particularly from the United Kingdom, can adequately demonstrate the competencies associated with working 
with different cultural and ethnic groups, a number of immigrant social worker applicants struggle to demonstrate competence to practise social work with Māori. This is mainly evident through the Practice Study and Self-reflection written work presented to the SWRB as part of the competency process.

Table two. Total registrations approved by Maori/Pasifika ethnicity 2004-2013.



As at May 2010 approximately nine percent of social workers with an initial overseas qualification were registered. The majority were from the United Kingdom and Ireland, followed by other European countries (Bartley et al. 2011: 20-21) and to date this remains relatively unchanged.

Under Section 13 of the Act, the Board is able to approve registration by recognition of prior learning and experience. This is primarily in cases in which social workers, while not having a recognised qualification, have satisfied the Board that their practical experience, competence and 'fit and proper' status have been adequately demonstrated. Section 13 requires significant input from applicants, as the requirements are set to a high standard. Comprehensive evidence is required to ensure that applicants meet the requirements for full registration under Section 13. In addition to assessing written material, in a number of cases the SWRB has undertaken face-to-face competency interviews with Section 13 applicants. This has proved to be an extremely reaffirming process for all those involved.

To date 132 social workers have had their full registration approved under Section 13 of the Act. While the majority of these social workers have come from Aotearoa New Zealand, others are from the United Kingdom, the United States, Canada, the Pacific Islands, Singapore and India.

The Board also has legislative responsibility for recognising degrees that lead to eligibility to apply for registration. It is acknowledged that it has been challenging for a number of education providers to ensure academic staff teaching in social work theory, skills and practice components in the training institutions are appropriately qualified and experienced. 
Across all sectors of the profession, social worker registration is seen by the majority of practitioners and their employers as an accepted measure to recognise competence and fitness to practise social work. Duke (2012: 10) opines that regulation through registration helps to differentiate those who are practising professional social work from those who are undertaking other tasks in the social service sector. In general, social workers have commented that registration gives a sense of professional identity, credibility, mana and prestige.

\section{Complaints and compliance}

Anyone can lodge a complaint against a registered social worker, either orally or in writing. However the SWRB Complaints and Disciplinary Tribunal can only accept complaints about the practice of registered social workers where there is an identified breach of the Code of Conduct.

\section{In 2000 the Ministry of Social Policy (MSP) stated:}

Social work has the potential to be a moderate to high risk occupation. It is difficult to assess the prevalence of poor social work practice. However, it is essential to protect the public from the outset by preventing poor practice and high risk situations from occurring. High risk situations may include misconduct, incompetence, malpractice or abuse.

In the past there has been comment on how registration might narrow the profession to one of accountability (Curson \& Randal, cited in Hutchings 2008: 3), however current SWRB data does not substantiate this concern. In the last two years, 46 complaints have been received in relation to registered social workers and seven in relation to unregistered social workers. In the main these complaints have been received from the general public and relate to concerns associated with perceived poor social work practice (MSP 2000: 4).

It is not uncommon for the SWRB to be one of a number of agencies that receive complaints about social work practice. In some instances the Privacy Commission, the Children's Commissioner, the Police, Child, Youth and Family, the Health and Disability Commission, MPs and Ministers of the Crown may all receive the same complaint.

The SWRB and the Complaints and Disciplinary Tribunal endeavour to work constructively and effectively with complainants, and with registered social workers who may be complained against. This is evidenced by the low number of complaints that have been referred to a Complaints Assessment Committee and/or have resulted in a full hearing of the Tribunal. The Tribunal often implements a conciliation process to achieve the best outcome for both complainants and the social workers concerned. Although the SWRB is unable to act on complaints against unregistered social workers, the Board nevertheless confers appropriately with complainants and keeps a record of such complaints.

Under the Act a complaint is referred to the Health and Disability Commission if the complainant is a consumer of a health service. For example, if a registered social worker is an employee of a district health board, the Health and Disability Commission is charged with the investigation and findings related to practice complaints.

Thirty-five social workers currently have compliance conditions attached to their annual practising certificates. Generally these are as a result of employers notifying the Board of concerns around individual social work practice issues. A number of social workers have, 
however, had their registration suspended as a result of not maintaining five-yearly recertification requirements, either through the ANZASW or the SWRB.

\section{Current challenges}

\section{Voluntary versus mandatory registration}

The major challenge currently facing social worker registration is that it is voluntary. Voluntary registration does not offer the same legal protection as mandatory registration, as the SWRB has oversight only of those who choose to register. Voluntary registration does not protect the 'social worker' title; at present anyone in Aotearoa New Zealand can call themselves a social worker. In the 2006 census some 13,170 people referred to themselves as social workers.

The current situation of voluntary registration for social workers is out of step with other similar professions. For example, pharmacists, midwives, nurses, dieticians, medical practitioners and occupational therapists are all subject to mandatory registration. Social work is the only profession in the health sector that does not have mandatory registration.

Other professionals that are required to be registered or licensed to practise include teachers, barristers and solicitors and recently, real estate agents.

In its 2011 'Mandatory Social Worker Registration - Report from the Discussion Paper' the Board of the SWRB determined that:

- voluntary registration does not meet the purposes of the Act;

- the public are at risk from poor social work practice by people using the title Social Worker outside the safety framework provide by the Act; and

- moving to mandatory registration is a fundamental step in reducing public risk from poor social work practice by improving the professionalism and accountability of social workers.

Its report was based on 422 submissions received from a range of individuals and groups in Aotearoa New Zealand, which showed that an overwhelming 95\% were in support of moving towards mandatory registration.

As part of its submission the ANZASW undertook its own membership opinion survey on the mandatory registration discussion paper. At the time this represented the views of 1,109 ANZASW members and of these, 51.5\% supported mandatory registration. This figure is significant when considering that $28 \%$ did not comment on whether they supported or opposed mandatory registration.

Feedback to date suggests that social worker registration is increasingly viewed by the majority of social workers and their employers as an appropriate measure to recognise and monitor on-going competence and fitness to practise social work.

\section{The cost of registration and APCs}

It is estimated that the overall cost of registration could decrease by up to $50 \%$ if it was to become mandatory. In its 'Statement of Intent 2013-2016' the Board reiterated, '...the 
economy of scale provided by mandatory registration would allow for a reduction in fees to approximately one half of the current cost' (p. 3).

As a Crown entity the Board is self-funding and relies on income generated by registration application fees and the issuing of annual practising certificates. No additional funding supports the SWRB. While the Board does not seek any direct Crown funding to support its regulatory functions, it nevertheless expects that, as with other registered professions, the profession as a body should be responsible for funding the SWRB. The Board has reiterated on a number of occasions that supporting a regulatory framework for an entire social work profession that is financially supported only by those social workers who voluntarily register, creates a distinct disadvantage to those registered practitioners in terms of the costs required to be met by them.

There is no doubt that the cost of initial competency whether through the ANZASW (by way of membership) or the SWRB, subsequent registration, the issuing of annual practising certificates, and the five-yearly recertification competency requirements all have significant financial implications for social workers and employers. Individuals and organisations have made regular and on-going comment on the costs associated with registration and the issuing of annual practising certificates. While the cost of registration has been significantly reduced in the last few years, in the current economic environment it is particularly difficult for the NGO sector to support the registration of its social work staff.

\section{Future challenges}

\section{Getting 'on board'}

Social work-qualified managers and professional leaders at all levels have the ability to assist in shaping the future face of social worker registration. They need to walk the talk. It could be argued that the current non-regulatory environment allows many such leaders to distance themselves from registration. It could also be argued that there is a professional imbalance of power when social work practitioners in front line positions are expected to meet the competency requirements for registration, and demonstrate on-going reflective practice and professional development, when those who are in social work leadership positions are not.

Social work leaders need to be committed to promoting and encouraging standards for the profession through registration. Social work not only encompasses face-to-face contact with clients, but also the management and supervision of social workers, teachers of social work practice and theory, and those who utilise social work knowledge, skills, values and ethics.

Agencies that employ social workers have an influence upon social work education (Wivell \& Naughton 2007: 33) and therefore ultimately it could be reasoned, registration. If registration becomes mandatory, how many social work-qualified managers, educators and leaders will be prepared to relinquish the title of 'social worker' if they choose not to register?

\section{NGO cost implications}

Mandatory registration would involve a significant number of social workers, many of whom are employed in the NGO sector. There is no contention that at present the cost of registration is placing an undue burden on NGOs. The SWRB is aware of cases where fully qualified social workers are being employed under the title of 'Community Support Worker' 
to undertake positions that entail experienced social work practice. It could be assumed that this is related to fiscal restraints around registration costs and salary differences.

In a number of instances, only those social workers in NGO supervisory positions are being supported to register. This may be aligned in part to Government contractual funding obligations; nevertheless all qualified social workers should be given the option to register without having to carry the full financial burden. It is common knowledge in the profession that social workers employed in the NGO sector are paid substantially less than those employed within the government sector.

It is estimated that $86 \%$ of NGO social workers are not registered. Therefore, the mandatory registration of all social workers is likely to be financially prohibitive for many NGOs. The Government would need to provide initial financial support, and ensure that NGOs have sufficient transitional time to plan and budget for the fiscal implications associated with registration and workforce development.

\section{Cyber social work}

Laptops, cellphones, video links, Facebook, webinars, twitter, emails, texting and video conferencing will increasingly becoming part of everyday practical and educational social work. This raises critical issues of privacy, confidentiality and professional boundaries. Social media has the ability to influence social work and social workers in ways that might have seemed incongruous in the past. Already in Aotearoa New Zealand, social work is increasingly being undertaken by means of telecommunication. Social workers are more often required to undertake initial assessments, make decisions on accepting and prioritising cases, and determine future direction, all without the benefit of face-to-face contact.

It is speculative to try and fully comprehend how registration might be affected by the growth of cyber social work in the future. However, it is critical that such work is cognisant of, and adheres to, both the SWRB Code of Conduct and the ANZASW Code of Ethics to ensure that it remains professional, principled and responsible. Mandatory registration, and its competency and recertification processes, will support social workers to regularly examine and reflect on their competencies and ethics in the increasing world of cyber social work.

\section{Cultural considerations}

The profession of social work is increasingly becoming more global as is its workforce, and in future this is likely to have further volume, verification and associated involvement for the registration of social workers with an overseas qualification. Bartley et al. (2011: 17) support the view that the international movement of social workers has implications in terms of aiming for a more consistent approach associated with regulation. They comment on the need to not only aim for, '...consistency within and between qualifications to facilitate portability,' but also for reconciliation around regulatory requirements.

With Aotearoa New Zealand being close to the top of the OECD rates in terms of immigration, our population is expected to reach five million in 2031 (Spoonley 2013: 21). Social work currently remains on the Government's Skilled Migrant List as a preferred immigrant applicant category. While most overseas-trained social workers currently applying for registration have completed their qualifications in English, this could change as the diversity of immigrant applicants increases. Our growth in cultural diversity presents unique challenges 
for those who are not only engaged in the practice of social work, but for immigrant social workers who wish to demonstrate competencies sufficient to attain social worker registration in Aotearoa New Zealand.

\section{Academic research}

While a number of individual social workers have commented on the worth of social work registration (McKinley 2006: 22-24) at present it is difficult to illustrate the benefits of registration. To date there appears to be little empirical research undertaken in Aotearoa New Zealand into the benefits (or otherwise) for clients who receive the services of social workers who are registered practitioners under the Social Workers Registration Act. There is a similar paucity of international research or evaluation of how well mandatory registration in other countries is working, whether social work practice has improved, its effects on the profession and / or whether the public's protection has been enhanced by registration. The Board is keen to address these gaps in research and evaluation, and is currently working on proposals to develop a research project on the benefits of social worker registration in New Zealand.

\section{Conclusion}

The Social Workers Registration Act 2003 sets out three clear key directives. These are:

- to protect the public by ensuring that social workers are competent to practise and be accountable for the way in which they practise;

- to promote the benefits of registration to the public, employers and any other bodies or organisations that interact with social workers; and

- to enhance the professionalism of social workers through support, education, development and regulation.

In 2006 Shannon Pakura, the then General Manager of Service Development at Child, Youth and Family said, 'Registration is the key to building and retaining confidence in our profession. It is a crucial step forward in our journey towards raising the status of the social work profession and ensuring quality social practice in New Zealand' (Pakura 2006: 2).

Social work in Aotearoa New Zealand has come a long way as a profession since the first university-based course was set up at Victoria University in the 1950s.

In our increasingly complex world, competent social work practitioners are required to have an enormous kete of expertise. Social work requires skills, knowledge, ethics, cultural cognisance, integrity, compassion, empathy and care. It also involves partnership, empowerment, human rights and social justice. These critical elements of social work although interchangeable, are intertwined and interlinked.

The public must have confidence in the profession of social work and social workers, and the veracity of the profession must remain intact. Social work must develop and grow to meet challenging situations, changing demographics and professional accountability.Social worker registration offers uniformity across a diverse professional entity. It provides a clear pathway towards enhancing social work practice and ensuring that those delivering the service are competent, professional and accountable. Importantly, people who are recipients 
of, or who use social work services need to have some assurance of the competence of their social worker. Registration helps to ensure this.

\section{References}

Bartley, A., Beddoe, L., Duke, J., Fouche, P., Harington, P., \& Shah, R. (2011). Crossing borders: Key features of migrant social workers in New Zealand. Aotearoa New Zealand Social Work Review XX111 (3): 16-30.

Beddoe, L. (2006). Registration and continuing education for social work in New Zealand - what about the workers? Aotearoa New Zealand Social Work Review XV111 (4): 100-111.

Betteridge, L. (2012). Social media and practice: Protecting privacy and professionalism in a virtual world. Fall issue of Perspective. Ontario College of Social Workers and Social Service Workers. Available from http./ / www. ocswssw.org/en/practice_notes.htm.

Bibus III, A., \& Boutte-Queen, N. (2011). Regulating social work - A primer on licensing practice. Lyceum Books: Chicago, Illinois.

Corrigan, R. (2000). Position paper on the statutory registration of social workers. Aotearoa New Zealand Social Work Review X11 (2): 3-7.

Dodds, I. (2004). A contemporary framework for the accountability of social workers' practice. Aotearoa New Zealand Social Work Review XV1 (1): 2-5.

Duke, J. (2012). Registration and professional practice. Social Work Now. The Practice Journal of Child, Youth and Family 51.

Hancock, M. (2004). Building an ethical social work profession. Aotearoa New Zealand Social Work Review XV1 (1): 1.

Hocquard. T. (2011). Social Workers Registration Act 2003. Presentation the Biannual AASW Queensland \& Queensland Branch Conference 'Advance Australia Fair? The Role of Social Work in Achieving Social Justice and Human Rights.'

Hutchings, J. (2008). Does social work registration have implications for social work supervision? Aotearoa New Zealand Social Work Review XX (1): 2-9.

Lynch, A. (2006). The place of structural-self reflexivity in our ongoing educational journal as social workers. Aotearoa New Zealand Social Work Review XV111 (4): 78-89.

McKinley, S. (2006). Coming into line with other professions. Social Work Now. The Practice Journal of Child, Youth and Family 34.

McKinley, S., \& Duke, J. (2012). New Zealand Social Work Education Review. Presentation at the IFSW International Conference. Stockholm.

Ministry of Social Development (2012a). The White Paper for Vulnerable Children.

Ministry of Social Development (2012b). The Children's Workforce Action Plan.

Ministry of Social Development Child, Youth and Family. (2012). 'Mā mātou, mā tātou changing young lives.'

Ministry of Social Policy. (2000). Registration of social workers discussion paper. Wellington: Ministry of Social Policy.

Pakura, S. (2006). Shannon Pakura discusses Child, Youth and Family and social worker registration. Social Work Now. The Practice Journal of Child, Youth and Family 34.

Pitt, L. (2005) Social work registration: Knowledge and power. Aotearoa New Zealand Social Work Review XV11 (3): 41-42.

Social Workers Registration Board (2011). Mandatory Social Worker Registration. A Discussion Paper. Wellington: Social Workers Registration Board.

Social Workers Registration Board. (2012). Annual Report 2011-2012. Social Workers Registration Board: Wellington.

Social Workers Registration Board. (2012). Statement of Intent 2012-2015. Social Workers Registration Board: Wellington.

Social Workers Registration Board. (2013). Statement of Intent 2013-2016. Social Workers Registration Board: Wellington.

Spoonley, P. (2013). Demography defining NZ. Massey University. Issue 23.

Wivell, J., \& Naughton, M. (2007). Diverse pipers, discordant tunes? Delivering robust social work education in an environment of new legislation and competing influences. Aotearoa New Zealand Social Work Review (Summer): 32-39. 